\title{
害展 望蔁
}

\section{第 57 回大会によせて}

佐々木 和 夫

Kazuo SASAKI

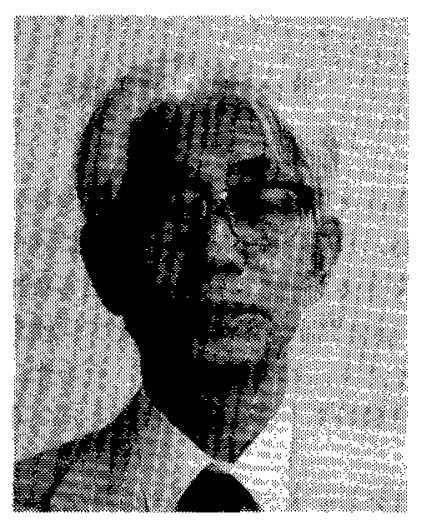

第 57 回大会が 4 月 5 日から 3 日間にわたり, 京都大学を会場に 開催されます。

今年は, 電気化学協会関西支部の創立 50 周年にあたりますので, 理事会に特にお願いして関西地区での開催に至ったものであります.

当協会も，昨年内には会員数三千を超すに至り，隆昌の気運が見 えることはご同慶に耐えません．その中で, 関西支部管内の会員数 は 640 名の程度と見られ，関東支部に次ぐ会員数を攡し，協会運営 に少なからぬ奇与を果たして参りました。

一ロに 50 年と申しますが, Galvani, Volta のことはともあれ， 水素電極反応理論に端を発する電極反応論, 金属腐食を科学の対象 に引き揚げるよすがとなった混成電位の概念, 更には 21 世紀のエ ネルギー問題解決の一翼を担うであろう半導体・光電気化学等々, すべてはこの半世紀のうちに形造られ，発展したわけですから，関 西支部 50 年の歴史は, 近代電気化学の発展と共にあったことに, 今更ながら想いを致す次第です.

昨年, 京都で行われた ISE 大会は 1200 を超える参加者を得て， 会長であるTrasatti 氏も，我国の電気化学の実況に少なからぬ警 異を感じた様子でした. 支部の隆盛は協会の隆盛であり, 協会の隆 盛は世界電気化学の隆盛にもつながります。一昨年，この誌面を借 りて, 武井 武先生のお話をご紹介させて頂きましたが（88 年 5 月号), 第 57 大会を, 武井先生の申されるような国際的学会の第一 歩としたいあのであります。

関西支部創立 50 周年を記念する意味で, 今回の企画の中には, 石野俊夫先生による記念講演の他に, 支部の将来を担う少壮研究者 十数名の方々による特別講演会が設けられてあります，50年の節 目にあたり，先達の歩まれた過ぎこしこの方を振り省ると共に，21 世紀の未来に向けての夢や理想を語り合おうというのが企画した立 場の者の願いであります.

全国から，多数の会員諸賢にご参集頂き，花を添えて頂くようお 願い致します。 